\title{
Editorial: On IRIE Vol. 26
}

Marx is en vogue. That is a matter of fact - not (only) due to the $200^{\text {th }}$ anniversary of his birthday in 2018. It's the issues Marx has dealt with (exploitation, alienation, inequalities etc.) that are (still) omnipresent and that keep his struggle with them modern over the years and years to come.

While Marx himself never finished his own elaborations on them he inspired many followers to do so (followers: what a modern term as well - Marx definitely would be a twitter star). That is both, a blessing and a curse. So many epigones claim Marxism for their (non-Marxian) purposes; they found a useful interpretation for their changing of the world to their own advantage (how ironic). On the other hand, so many scholars gained both: a strong motivation as well as an intellectual approach to ask the right questions and find the right answers to improve the conditions of the socially deprived and deal with injustice, poverty and overcoming social disadvantages.

As a philosopher, the best way to handle this area of tension is: "Forget about Marxism, read Marx!" If you look into the references in this issue that is what our authors have done and the insights they found on the interplay between the ideas of Marx and the issues of information ethics are both profound and inspiring themselves. But forget about this foreword, read the issue!

Sincerely yours,

the editors of IRIE 